\title{
Community structure and species composition of a periodically flooded Restinga forest in Caraguatatuba, São Paulo, Brazil
}

\author{
Marcelo Petratti Pansonato ${ }^{I *}{ }^{\mathbb{D}}$, Renato Augusto Ferreira de Lima ${ }^{I}$, Alexandre Adalardo de Oliveira ${ }^{I}$, \\ Ricardo Bertoncello $^{I}$ \& Adriana Maria Zanforlin Martini ${ }^{1}$ \\ ${ }^{1}$ Universidade de São Paulo, Instituto de Biociências, Rua do Matão, $n^{\circ} 321$, 05508-090, São Paulo, SP, Brasil \\ *Corresponding author: Marcelo Pansonato,e-mail: marcelopansonato@hotmail.com \\ PANSONATO, M.P., LIMA, R.A.F.; OLIVEIRA, A.A., BERTONCELLO, R., MARTINI, A.M.Z. Community \\ structure and species composition of a periodically flooded Restinga forest in Caraguatatuba, São Paulo, \\ Brazil. Biota Neotropica. 19(1): e20170477. http://dx.doi.org/10.1590/1676-0611-BN-2017-0477
}

\begin{abstract}
The aim of this study was to characterize the structure and composition of the tree and shrub community in a 77-ha fragment of Restinga forest in Caraguatatuba, São Paulo, Brazil. In this fragment, forty $20 \times 20-\mathrm{m}$ plots (1.6 ha) were systematically allocated and all trees with a stem diameter at breast height $(\mathrm{DBH}) \geq 4.8 \mathrm{~cm}$ were sampled. Sixteen plots were randomly chosen to also sample individuals with a DBH of between 1 and $4.8 \mathrm{~cm}$. All individuals were tagged, identified to species level, and their diameters and heights were measured. A total of 2587 individuals (1616 ind./ha) from 119 species and 42 families were found with a DBH $>4.8 \mathrm{~cm}$, and 2659 individuals (4154 ind./ha) from 125 species and 38 families were found with a DBH $>1 \mathrm{~cm}$. The richest families were Myrtaceae, Lauraceae, and Fabaceae, and the most abundant species were Diospyros brasiliensis (Ebenaceae), Anaxagorea dolichocarpa (Annonaceae), and Euterpe edulis (Arecaceae). The structure of the studied site was similar to that of other Restinga forest sites, but the forest composition was quite distinct. Implications for the conservation and restoration of Restinga forests in this region are discussed in light of the results obtained.
\end{abstract}

Keywords: white sandy soil, coastal sandy forest, waterlogging, coastal plain vegetation, Atlantic Forest.

\section{Estrutura e composição de espécies de uma floresta de Restinga periodicamente alagada em Caraguatatuba, São Paulo, Brasil}

\begin{abstract}
Resumo: O objetivo deste estudo foi caracterizar a estrutura e composição da comunidade arbórea e arbustiva em um fragmento de 77 ha de floresta de Restinga em Caraguatatuba, São Paulo. Neste fragmento, 40 parcelas de 20 $\times 20 \mathrm{~m}$ (1,6 ha) foram distribuídas sistematicamente e todas as árvores com diâmetro do tronco na altura do peito (DAP) $\geq 4,8 \mathrm{~cm}$ foram amostradas. Além disso, 16 parcelas foram escolhidas aleatoriamente para amostrar também todos os indivíduos com DAP entre 1 e $4.8 \mathrm{~cm}$ de DAP. Todos os indivíduos foram marcados, identificados ao nível de espécie e tiveram seu diâmetro e altura medidos. Para indivíduos acima de 4,8 $\mathrm{cm}$ de DAP, foi amostrado um total de 2587 indivíduos (1616 ind./ha) em 119 espécies e 42 famílias. Para indivíduos acima de 1 cm de DAP, foi amostrado um total de 2659 indivíduos (4154 ind./ha) em 125 espécies e 38 famílias. As famílias mais ricas foram Myrtaceae, Lauraceae e Fabaceae. As espécies mais abundantes foram Diospyros brasiliensis, Anaxagorea dolichocarpa e Euterpe edulis. Quando comparado com outros locais de florestas de Restinga, a estrutura florestal do fragmento estudado é semelhante a outras florestas de Restinga. No entanto, a composição da floresta é bastante distinta, evidenciando a heterogeneidade das florestas de Restinga ao longo da costa do Brasil. Implicações para a conservação e restauração das florestas de Restinga são destacadas.
\end{abstract}

Palavras-chave: solo arenoso, floresta sobre areia, alagamento, vegetação da planície costeira, Mata Atlântica. 


\section{Introduction}

The Atlantic Forest domain harbors a great diversity of forest types, whose characteristics are defined primarily by climatic and topographic factors. However, soils are also an important factor for determining some forest types, such as Restinga forests (also called coastal sandy forests), which are established on Quaternary marine sand deposits. In such edaphic communities, variations in soil properties (e.g., soil texture, nutrient levels, and aluminum content) and groundwater dynamics largely determine variations in forest structure and composition (Scarano 2002, Magnago et al. 2012, Oliveira et al. 2014). As the water table is usually shallow in Restinga forests, tree roots are often subjected to some level of waterlogging (Maun 1994, Scarano 1998). Restinga forests subjected to long-lasting or permanent flooding tend to have low species richness and can show patterns of high species dominance (Galvão et al. 2002, Kurtz et al. 2013), while forests with intermittent flooding regimes tend to harbor more species (Guedes et al. 2006, Marques et al. 2009, Magnago et al. 2012). Although these diversity patterns are well known, there are uncertainties regarding some aspects of Restinga forest structure, such as stem density (Guedes et al. 2006, Marques et al. 2009, Magnago et al. 2012, Oliveira et al. 2014), patterns of species abundance, and the distribution and identity of the most abundant species (Galvão et al. 2002, Martins et al. 2008, Menezes et al. 2010, Assis et al. 2011, Oliveira et al. 2014). Therefore, new inventories are required to improve our understanding of Restinga forest structural and compositional variation.

In the state of São Paulo, Brazil, more surveys have been conducted on rainforests on clayey soils than on Restinga forests (Lima et al. 2015), so information gaps of the Restinga forest still remain along the $400-\mathrm{km}$ coastline (Marques et al. 2011, Lima et al. 2015 and references therein). The south coast of São Paulo has been the most studied (Carvalhaes 1997, Sugiyama 1998, Sztutman \& Rodrigues 2002, Carrasco 2003, Lima et al. 2011, Oliveira et al. 2014), while studies in central and northern regions have concentrated on the municipalities of Bertioga (Guedes et al. 2006, Lopes 2007, Martins et al. 2008) and Ubatuba (Cesar \& Monteiro 1995, Assis 1999, Assis et al. 2011). Although Caraguatatuba is the largest coastal plain in the northern region, only one study has been conducted in this municipality (Mantovani 1992).

Since the 1970s, the Caraguatatuba region and surroundings municipalities have been converted into urban areas, livestock farms, and more recently, industrial areas. Currently, $63 \%$ of the Caraguatatuba coastal plain has been deforested, and most of the forest remnants are small and scattered across the landscape (Souza 2006, Souza \& Luna 2008). Knowledge of the different types of vegetation in this region is fundamental to future conservation and restoration strategies. In this study, the structure and composition of a forest fragment in this poorly studied region of the coastal plain were investigated, and the importance of the area for regional conservation strategies was highlighted.

\section{Material and Methods}

\section{Study site}

The study was conducted in a $\sim 77$-ha Restinga forest fragment on the sandy coastal plain of Caraguatatuba on the north coast of São Paulo

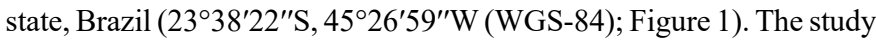

siteIt is located on property owned by a local resident, and is surrounded by a heterogeneous matrix of urban occupation eastward, pastures on its southern and western limits, and low-altitude rainforests on the northern boundary. The terrain is almost flat, and the elevation varies between 6 and $8 \mathrm{~m}$ above sea level. Due to variations in microtopography, the lowest areas are more susceptible to flooding, and are flooded for between a few days to over a month during rainy periods, particularly the summer. Even in the driest period of the year, the water table is shallow $(\sim 30-50 \mathrm{~cm})$, so the area floods after occasional heavy rain. Only a small proportion of our study site is established on sand ridges with well-drained soils. Evidence of palm-heart harvesters, hunting, and domestic animals were found in our study site. Although no evidence of selective wood extraction was found during the fieldwork, it is possible that Tabebuia cassinoides was extracted in the past for its traditional use in handicrafts and oar-making (Borges \& Peixoto 2009). However, our study site seems to be relatively well-conserved, because there were no signs that any major disturbances had occurred there, as observed in aerial photographs taken from 1967 to 2016, except for a small-scale deforestation event that occurred in a 100-m strip in 1990. Information regarding the secondary vegetation in this strip is provided as Supplementary Material.

The dominant soils in the region are Quartzarenic Neosols and Spodosols, according to Oliveira et al. (1999). These soils are sandy to sandy-clayey, very acidic, infertile, and have a high aluminum content (Table 1). The climate is tropical rainforest ( $A f$, following the Köppen classification), with hot, wet summers and cool, dry winters. The average annual temperature is $24.9{ }^{\circ} \mathrm{C}$, and the average temperatures of the hottest and coldest months are $26.5^{\circ} \mathrm{C}$ and $20^{\circ} \mathrm{C}$, respectively. The average annual precipitation is $1758 \mathrm{~mm}$. The dry season runs from April to September, and the driest month is July (average of $62.5 \mathrm{~mm}$ of precipitation). The wet season runs from October to March and the wettest month is January, with an average of $251.6 \mathrm{~mm}$ of precipitation (CEPAGRI 2016).

\section{Data collection and analysis}

Forty $20 \times 20$-m plots (total of 1.6 ha) were sampled from January 2013 to July 2014 . The plots were $80 \mathrm{~m}$ apart, systematically distributed in the area (Figure 1), and at least $30 \mathrm{~m}$ from the edge of the fragment. Only trees with a stem diameter at breast height $(\mathrm{DBH}) \geq 4.8 \mathrm{~cm}$ were included in all 40 plots. Individuals with a DBH of between 1 and $4.8 \mathrm{~cm}$, which included shrub species, were additionally sampled in 16 randomly taken plots (Figure 1). All trees and shrubs were tagged and had their diameters measured and their heights estimated. For multi-stemmed individuals, all stems were measured if at least one of them reached the DBH cutoff. After collection, plant specimens were identified by referring to the literature, checking herbarium specimens, and/or consulting experts. Easily identified species, such as Calophyllum brasiliense, Euterpe edulis, and other palms, were identified in the field. Vouchers of the species identified by experts and/or after herbarium checks were deposited in the herbarium of the Universidade de São Paulo, Campus Piracicaba (ESA) under the collection numbers of M.P. Pansonato. Some unicates that were not deposited in the ESA are available at the Laboratório de Ecologia de Florestas Tropicais of the Universidade de São Paulo. The nomenclature followed that of the Angiosperm Phylogeny Group IV (APG IV 2016). 

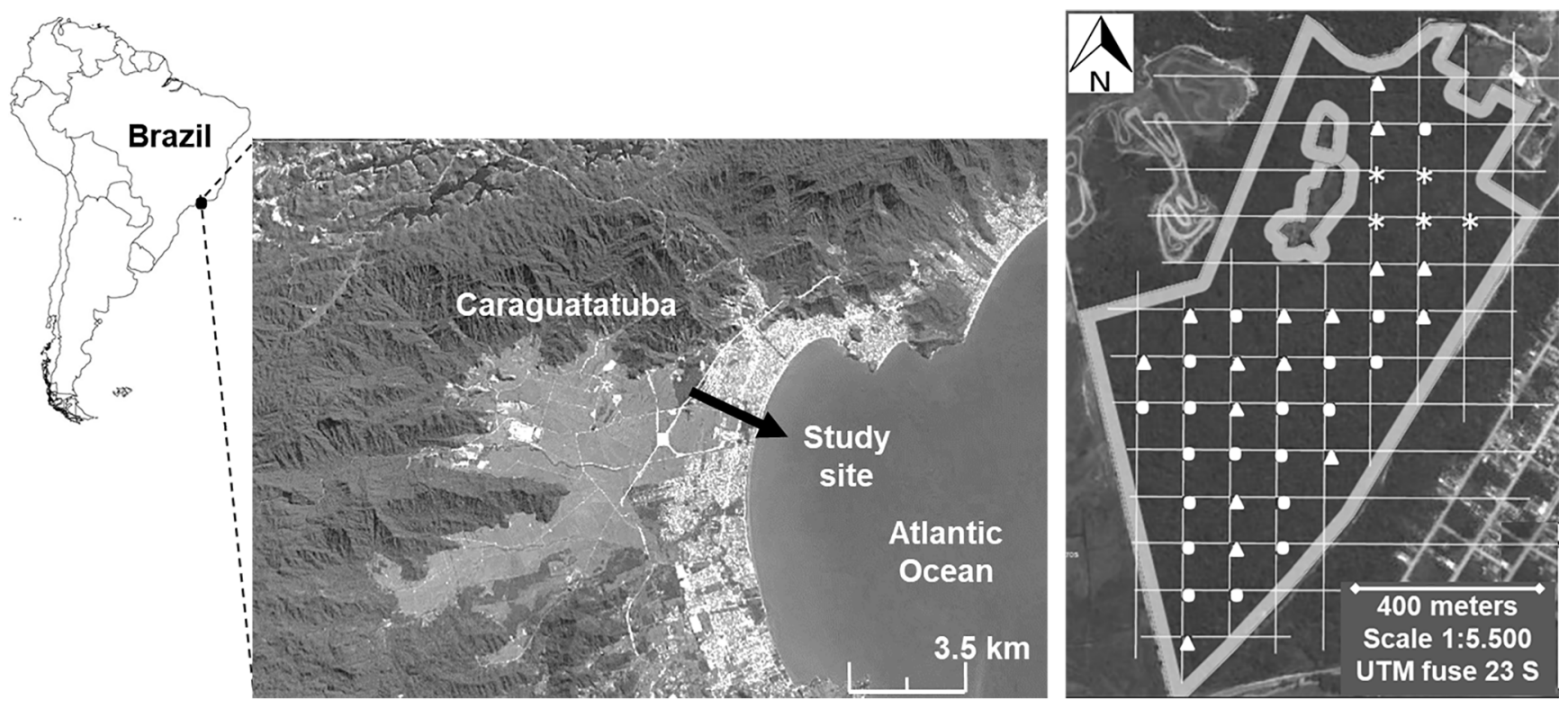

Figure 1. Location of the study site on the coastal plain of Caraguatatuba, SP, Brazil. In the central image, note the continuous forest cover (dark grey) surrounding the study site. In the right image, plots distributed systematically along the Restinga forest fragment are shown. Dots are plots sampled for DBH $\geq 4.8 \mathrm{~cm}$; Triangles are plots sampled for $\mathrm{DBH} \geq 1 \mathrm{~cm}$; Asterisks represents the five plots located on degraded strip (see supplementary material).

Table 1. Mean and amplitude (within parentheses) of topsoil $(0-5 \mathrm{~cm})$ chemical properties in the study site. Samples were collected in the center of each sampled plot.

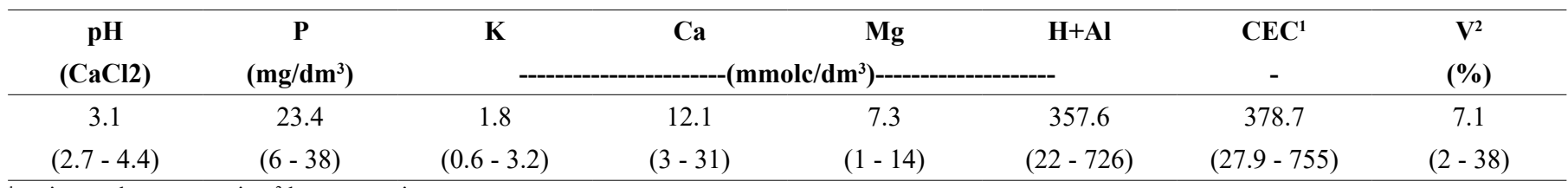

${ }^{1}$ cation exchange capacity; ${ }^{2}$ base saturation.

In order to compare our results with those in the literature, the forest structure and composition data are shown separately for three groups with distinct inclusion criteria: i) $\mathrm{DBH} \geq 1 \mathrm{~cm}$ from 16 plots; ii) $\mathrm{DBH} \geq 4.8 \mathrm{~cm}$ from 40 plots; iii) $\mathrm{DBH} \geq 10 \mathrm{~cm}$ from 40 plots. For each inclusion criteria, the number of individuals per hectare, relative density, basal area, relative dominance, the percentages of multi-stemmed individuals and singletons (species with one individual in the total sample), and the Shannon diversity index (H'; Magurran 1988) were calculated using FITOPAC 2.0 (Shepherd 2009). In order to obtain a better comparison of the values among the three DBH inclusion criteria, the number of species in the $\mathrm{DBH} \geq 4.8 \mathrm{~cm}$ and $\mathrm{DBH} \geq 10 \mathrm{~cm}$ inclusion criteria were rarefied by sample $(20 \times 20$-m plots $)$, and the mean species richness values for 0.64 ha and 1 ha, and their respective confidence intervals, were calculated. Sample-based rarefaction curves were calculated using the vegan package (Oksanen et al. 2016) in R 3.4.4 (R Foundation for Statistical Computing, Vienna, Austria).

\section{Results}

A total of 4222 individuals from 44 families and 141 species were sampled (Table 2). The results varied with the DBH inclusion criteria under consideration (Tables 3 and 4; see also Supplementary Material tables S1 and S2). The smaller the $\mathrm{DBH}$, the greater the tree density, species richness, and Shannon diversity index. The estimated species richness varied between 93 and 114 species per hectare for DBH $\geq 4.8 \mathrm{~cm}$, and between 73 and 89 species per hectare for $\mathrm{DBH} \geq 10 \mathrm{~cm}$ (Supplementary Material Figure S1). Sampling smaller individuals (between 1 and $4.8 \mathrm{~cm} \mathrm{DBH}$ ) had only a minor effect ( $3 \%$ increase) on the estimated basal area. The proportions of multi-stemmed individuals were similar among the three DBH inclusion criteria (Table 3), and 76 out of 141 species $(53.9 \%)$ had at least one multi-stemmed individual. Canopy height varied between 14 and $20 \mathrm{~m}$, with emergent trees reaching up to $25 \mathrm{~m}$.

The richest family in all of the DBH inclusion criteria was Myrtaceae, which had nearly twice the number of species than the second-richest (Lauraceae) (Supplementary Material Table S2). The peak in Myrtaceae, Rubiaceae, and Melastomataceae richness was found in the $\mathrm{DBH} \geq 1 \mathrm{~cm}$ group, as some species in these families do not have large diameters. The most abundant family in all of the DBH inclusion criteria was Ebenaceae, which was represented by only one species (Diospyros brasiliensis), and Myrtaceae was the second-most abundant family for all DBH inclusion criteria because of the abundance of many species (Supplementary Material Table S2). Annonaceae, Arecaceae, and Lauraceae were the most abundant families in the two lowest DBH inclusion criteria, being replaced by Euphorbiaceae and Bignoniaceae, in addition to Lauraceae, when $\mathrm{DBH} \geq 10 \mathrm{~cm}$. 
Pansonato, M. et al.

Table 2. Species list and voucher numbers in the herbarium of the Universidade de São Paulo - Campus Piracicaba (ESA) of a Restinga forest in Caraguatatuba - SP, Brazil.

\begin{tabular}{l} 
Family/Species \\
\hline Anacardiaceae \\
Tapirira guianensis Aubl. \\
Annonaceae \\
Anaxagorea dolichocarpa Sprague \& Sandwith \\
Guatteria australis A.St.-Hil. \\
Xylopia langsdorfiana A.St.-Hil. \& Tul. \\
Aquifoliaceae \\
Ilex dumosa Reissek \\
Ilex pseudobuxus Reissek \\
Ilex theezans Mart. ex Reissek \\
Araliaceae \\
Dendropanax monogynus (Vell.) Seem. \\
Oreopanax capitatus (Jacq.) Decne. \& Planch. \\
Schefflera angustissima (Marchal) Frodin
\end{tabular}

\section{Arecaceae}

Astrocaryum aculeatissimum (Schott) Burret

Attalea dubia (Mart.) Burret

Bactris setosa Mart.

Euterpe edulis Mart.

Geonoma schottiana Mart.

\section{Bignoniaceae}

Handroanthus albus (Cham.) Mattos

Handroanthus umbellatus (Sond.) Mattos

Jacaranda puberula Cham.

Tabebuia cassinoides (Lam.) DC.

Tabebuia sp. Gomes ex DC.

Boraginaceae

Cordia sellowiana Cham.

\section{Calophyllaceae}

Calophyllum brasiliense Cambess.

\section{Celastraceae}

Maytenus gonoclada Mart.

ESA 134420

ESA134421

ESA134422

ESA134423

\section{Clethraceae}

Clethra scabra Pers.

Clusiaceae

Garcinia gardneriana (Planch. \& Triana) Zappi

Cyatheaceae

Cyathea atrovirens (Langsd. \& Fisch.) Domin

\section{Ebenaceae}

Diospyros brasiliensis Mart. ex Miq.

ESA 134428

Elaeocarpaceae

Sloanea guianensis (Aubl.) Benth.

ESA134429

Euphorbiaceae

Alchornea triplinervia (Spreng.) Müll. Arg.

ESA 134430

Aparisthmium cordatum (A.Juss.) Baill.

ESA134431

Mabea piriri Aubl.

Maprounea guianensis Aubl.
Continuation Table 2.

\begin{tabular}{lr}
\hline Family/Species & Voucher \\
\hline Fabaceae & \\
$\quad$ Albizia pedicellaris (DC.) L.Rico & \\
Andira fraxinifolia Benth. & ESA134434
\end{tabular}

Hymenolobium janeirense Kuhlm.

Inga edulis Mart.

Inga sessilis (Vell.) Mart.

ESA134435

Inga striata Benth.

ESA134436

Machaerium nyctitans (Vell.) Benth.

Ormosia arborea (Vell.) Harms

ESA 134437

Pterocarpus rohrii Vahl

ESA134438

\section{Lacistemataceae}

Lacistema lucidum Schnizl.

\section{Lamiaceae}

Aegiphila integrifolia (Jacq.) Moldenke

Vitex polygama Cham.

\section{Lauraceae}

Aiouea saligna Meisn.

ESA134439

Aniba viridis $\mathrm{Mez}$

ESA134440

Cryptocarya mandioccana Meisn.

Endlicheria paniculata (Spreng.) J.F.Macbr.

ESA134441

Nectandra grandiflora Nees

Nectandra oppositifolia Nees

ESA134442

Ocotea aciphylla (Nees \& Mart.) Mez

ESA134443

Ocotea brachybotrya (Meisn.) Mez

Ocotea lanata (Nees \& Mart.) Mez

ESA134444

Ocotea mosenii $\mathrm{Mez}$

ESA134445

Ocotea pulchella (Nees \& Mart.) Mez

ESA134446

Ocotea venulosa (Nees) Baitello

ESA134447

Persea willdenovii Kosterm.

\section{Malvaceae}

Eriotheca pentaphylla (Vell. \& K.Schum.)

A.Robyns

ESA134448

\section{Melastomataceae}

Clidemia cf. urceolata DC.

Huberia ovalifolia DC.

ESA134449

Miconia cinnamomifolia (DC.) Naudin

Miconia dodecandra Cogn.

ESA 134450

Miconia prasina (Sw.) DC.

ESA134451

Miconia pusilliflora (DC.) Naudin

ESA134452

Ossaea sp. DC.

Tibouchina pulchra Cogn.

ESA134454

Tibouchina stenocarpa (Schrank \& Mart. ex DC.)

ESA134453

Cogn.

\section{Meliaceae}

Cabralea canjerana (Vell.) Mart.

Guarea macrophylla Vahl

ESA134455

Trichilia pallens C.DC.

Monimiaceae

Mollinedia cf. ovata Ruiz \& Pav. 
Continuation Table 2.

\begin{tabular}{|c|c|}
\hline Family/Species & Voucher \\
\hline Mollinedia schottiana (Spreng.) Perkins & ESA134456 \\
\hline \multicolumn{2}{|l|}{ Moraceae } \\
\hline \multicolumn{2}{|l|}{ Ficus enormis Mart. ex Miq. } \\
\hline Ficus gomelleira Kunth & ESA134458 \\
\hline \multicolumn{2}{|l|}{ Ficus insipida Willd. } \\
\hline Ficus pulchella Schott & ESA134457 \\
\hline Sorocea jureiana Romaniuc & ESA134459 \\
\hline \multicolumn{2}{|l|}{ Myrtaceae } \\
\hline Blepharocalyx salicifolius (Kunth) O.Berg & ESA134460 \\
\hline \multicolumn{2}{|l|}{ Calyptranthes concinna DC. } \\
\hline Calyptranthes lucida Mart. ex DC. & ESA134461 \\
\hline Eugenia astringens Cambess. & ESA134462 \\
\hline Eugenia brasiliensis Lam. & ESA134463 \\
\hline Eugenia cerasiflora Miq. & ESA134464 \\
\hline \multicolumn{2}{|l|}{ Eugenia cereja D.Legrand } \\
\hline \multicolumn{2}{|l|}{ Eugenia melanogyna (D.Legrand) Sobral } \\
\hline Eugenia monosperma Vell. & ESA134465 \\
\hline Eugenia neoglomerata Sobral & ESA134466 \\
\hline Eugenia oblongata O.Berg & ESA134467 \\
\hline Eugenia stigmatosa DC. & ESA134468 \\
\hline Eugenia sulcata Spring ex Mart. & ESA134469 \\
\hline Marlierea clausseniana (O.Berg) Kiaersk. & ESA134470 \\
\hline Marlierea racemosa (Vell.) Kiaersk. & ESA134471 \\
\hline Marlierea tomentosa Cambess. & ESA134472 \\
\hline Myrcia brasiliensis Kiaersk. & ESA134473 \\
\hline Myrcia glabra (O.Berg) D.Legrand & ESA134474 \\
\hline Myrcia hexasticha Kiaersk. & ESA134475 \\
\hline Myrcia multiflora (Lam.) DC. & ESA134476 \\
\hline Myrcia pubipetala Miq. & ESA134477 \\
\hline Myrcia racemosa (O.Berg) Kiaersk. & ESA134478 \\
\hline Myrcia spectabilis DC. & ESA134479 \\
\hline Myrcia splendens (Sw.) DC. & ESA134480 \\
\hline Psidium cattleianum Sabine & ESA134481 \\
\hline Syzygium jambos (L.) Alston * & ESA134482 \\
\hline \multicolumn{2}{|l|}{ Nyctaginaceae } \\
\hline Guapira hirsuta (Choisy) Lundell & ESA134483 \\
\hline Guapira opposita (Vell.) Reitz & ESA134484 \\
\hline Pisonia sp. L. & ESA134485 \\
\hline \multicolumn{2}{|l|}{ Ochnaceae } \\
\hline Ouratea multiflora (Pohl) Engl. & ESA134486 \\
\hline Ouratea parviflora (A.DC.) Baill. & ESA134487 \\
\hline \multicolumn{2}{|l|}{ Olacaceae } \\
\hline Heisteria silvianii Schwacke & ESA134488 \\
\hline \multicolumn{2}{|l|}{ Peraceae } \\
\hline \multicolumn{2}{|l|}{ Pera glabrata (Schott) Poepp. ex Baill. } \\
\hline \multicolumn{2}{|l|}{ Phyllanthaceae } \\
\hline Hyeronima alchorneoides Allemão & ESA134432 \\
\hline
\end{tabular}

Continuation Table 2.

\begin{tabular}{lr}
\hline Family/Species & Voucher \\
\hline Piperaceae & \\
$\quad$ Piper gaudichaudianum Kunth & ESA134489 \\
Podocarpaceae & \\
$\quad$ Podocarpus sellowii Klotzsch ex Endl. & ESA134490
\end{tabular}

\section{Primulaceae}

Myrsine coriacea (Sw.) R.Br. ex Roem. \& Schult.

ESA134491

Myrsine guianensis (Aubl.) Kuntze

Myrsine venosa A.DC.

ESA 134492

Stylogyne lhotzkyana (A.DC.) Mez

ESA134493

\section{Rosaceae}

Prunus myrtifolia (L.) Urb.

ESA134494

\section{Rubiaceae}

Amaioua intermedia Mart. ex Schult. \& Schult.f.

ESA134495

Cordiera cf. myrciifolia (K.Schum.) C.H.Perss. \&

ESA 134496

Delprete

Ladenbergia hexandra (Pohl) Klotzsch

Posoqueria latifolia (Rudge) Schult.

ESA134497

Psychotria hastisepala M. Arg.

Psychotria hoffmannseggiana (Willd. ex Schult.)

ESA134498

M. Arg.

Psychotria mapourioides DC.

Rudgea coriacea (Spreng.) K.Schum.

ESA134499

\section{Rutaceae}

Zanthoxylum rhoifolium Lam.

\section{Sapindaceae}

Matayba intermedia Radlk.

ESA134500

\section{Sapotaceae}

Ecclinusa ramiflora Mart.

ESA134501

Manilkara subsericea (Mart.) Dubard

Pouteria beaurepairei (Glaz. \& Raunk.) Baehni

ESA134502

ESA 134503

Pouteria psammophila (Mart.) Radlk.

ESA134504

Siparunaceae

Siparuna brasiliensis (Spreng.) A.DC.

ESA134505

\section{Styracaceae}

Styrax glabratus Schott

ESA 134506

\section{Symplocaceae}

Symplocos estrellensis Casar.

Theaceae

Laplacea fructicosa (Schrad.) Kobuski

\section{Thymelaeaceae}

Daphnopsis racemosa Griseb.

ESA134507

Daphnopsis schwackeana Taub.

ESA134508

Cecropia glaziovii Snethl.

ESA134509

* Exotic species. 
Pansonato, M. et al.

Table 3. Community-level attributes for three diameter at breast height (DBH) inclusion criteria of a Restinga forest fragment located on coastal plain of Caraguatatuba, Brazil.

\begin{tabular}{|c|c|c|c|}
\hline \multirow{2}{*}{ Atribute } & \multicolumn{3}{|c|}{ DBH inclusion criteria } \\
\hline & $\geq 1(0.64 \mathrm{ha})$ & $\geq 4.8(1.6 \mathrm{ha})$ & $\geq 10$ (1.6 ha) \\
\hline Total of individuals & 2659 & 2587 & 1268 \\
\hline Basal area $\left(\mathrm{m}^{2} / \mathrm{ha}\right)^{\#}$ & $31.76 \pm 13.3$ & $30.9 \pm 10.9$ & $27.08 \pm 11.1$ \\
\hline Multi-stemmed (\%) & 14.7 & 15.7 & 13.4 \\
\hline Species/0.64ha* & 125 & $90(77-103)$ & $69(59-79)$ \\
\hline Shannon & 3.64 & 3.61 & 3.41 \\
\hline Singletons (\%) & 24.8 & 24.4 & 26.3 \\
\hline Families & 38 & 42 & 37 \\
\hline
\end{tabular}

Table 4. Relative densities (\%) and ranking order (within parentheses) of 15 most abundant species for $\mathrm{DBH} \geq 1 \mathrm{~cm}$ and their values for larger diameter at breast height (DBH) inclusion criteria sampled in a Restinga forest fragment located on coastal plain of Caraguatatuba, Brazil.

\begin{tabular}{lccc}
\hline \multirow{2}{*}{ Species } & \multicolumn{3}{c}{ DBH inclusion criteria } \\
\cline { 2 - 3 } Diospyros brasiliensis & DBH $\geq \mathbf{1}(\mathbf{0 . 6 4} \mathbf{h a})$ & DBH $\geq \mathbf{4 . 8}(\mathbf{1 . 6} \mathbf{h a})$ & DBH $\geq \mathbf{1 0}(\mathbf{1 . 6} \mathbf{h a})$ \\
Anaxagorea dolichocarpa & $13.8(1)$ & $19.1(1)$ & $23.8(1)$ \\
Euterpe edulis & $11.5(2)$ & $6.3(2)$ & $2.4(12)$ \\
Tabebuia cassinoides & $5.7(3)$ & $6.3(3)$ & $0.2(50)$ \\
Guarea macrophylla & $5.1(4)$ & $3.5(7)$ & $4.5(5)$ \\
Nectandra oppositifolia & $4.2(5)$ & $2.6(10)$ & $0.6(32)$ \\
Eugenia monosperma & $3.8(6)$ & $3.1(8)$ & $4.5(4)$ \\
Sloanea guianensis & $3.3(7)$ & $5.1(4)$ & $3.5(8)$ \\
Aniba viridis & $3.3(8)$ & $4.2(5)$ & $4.7(3)$ \\
Bactris setosa & $2.8(9)$ & $0.9(28)$ & $0.2(57)$ \\
Guapira opposita & $2.7(10)$ & $0.4(43)$ & - \\
Schefflera angustissima & $2.4(11)$ & $1.4(17)$ & $1.5(15)$ \\
Alchornea triplinervia & $2.4(12)$ & $2.8(9)$ & $3.4(9)$ \\
Stylogyne lhotzkyana & $2.3(13)$ & $3.5(6)$ & $5.7(2)$ \\
Myrcia racemosa & $2.3(14)$ & $0.6(36)$ & $0.2(58)$ \\
\hline
\end{tabular}

A strong dominance by one species, in terms of the number of individuals, was observed in all of the DBH inclusion criteria considered. Diospyros brasiliensis had the highest abundance, basal area, and frequency values in all of the DBH inclusion criteria (Table 4 and Supplementary Material Table S1). Anaxagorea dolichocarpa, Euterpe edulis, and Alchornea triplinervia were the second-most abundant species in $\mathrm{DBH} \geq 1 \mathrm{~cm}, \mathrm{DBH} \geq 4.8 \mathrm{~cm}$, and $\mathrm{DBH} \geq 10 \mathrm{~cm}$, respectively (Table 4 and Supplementary Material Table S1). For DBH $\geq 1 \mathrm{~cm}$, the threatened species E. edulis and Tabebuia cassinoides were also well represented as regenerating individuals (Table 4). Only one exotic species (Syzygium jambos) was sampled, with three individuals. Nectandra oppositifolia had relatively high basal area values because it can grow to a great size ( $\mathrm{DBH} \geq 60 \mathrm{~cm}$ ). Tapirira guianensis, Calophyllum brasiliense, and Manilkara subsericea had the highest
$\mathrm{DBH}$ and height values. Only around 10 species were present in more than a half of the plots, and almost a quarter of the species were only found in one plot, irrespective of $\mathrm{DBH}$.

\section{Discussion}

Tree density in the study area (1616 ind./ha for $\mathrm{DBH} \geq 4.8 \mathrm{~cm}$ ) was lower than the average density estimated from 14 Restinga forests in São Paulo state (1442-2756 ind./ha, average 1907 ind./ha; see Lima et al. 2015 and references therein). In addition, the tree density for $\mathrm{DBH} \geq 1 \mathrm{~cm}$ (4154 ind./ha) had similar values to the only study of our knowledge that has used this inclusion criteria (3533-4256 ind./ha, average 3895 ind./ha in Oliveira et al. 2014). Differences in tree density could be caused by abiotic factors such as flooding period (Menezes 
et al. 2010, Marques et al. 2015). Restinga forests that are susceptible to flooding seem to have a greater stem density than those that are not (Guedes et al. 2006, Magnago et al. 2012). However, some studies have found the opposite pattern (e.g., Marques et al. 2009) or no significant differences in stem density between flooded and unflooded Restinga forests (Oliveira et al. 2014). This suggests that other ecological factors could also be relevant, such as successional stage (Chazdon 2003).

In general, forests in early successional stages tend to have greater stem density and lower biomass than old-growth forests (Chazdon et al. 2009). Thus, the low density found in our study site when compared with other Restinga forests could be indicative of the relatively well-conserved status of this site, besides the five recognized secondary plots (see Supplementary Material Table S3). However, the lower density observed could also have been a consequence of harvesting Euterpe edulis (101 ind./ha), which probably had long-lasting effects that continue today. In addition, the selective extraction of Tabebuia cassinoides individuals (56 ind./ha), which is not currently evident but probably occurred in the past, could also have contributed to the low stem density values obtained. Despite their high relative abundances in this study, these species are usually found at much higher densities in Restinga forests that are susceptible to flooding (for example, 639 ind./ha of E. edulis in Rotta et al. 1997, 365 ind./ha in Vanini 1999, and 293.8 ind./ha in Oliveira et al. 2014). However, the E. edulis density found for $\mathrm{DBH} \geq 1 \mathrm{~cm}$ (237 ind./ha) may indicate that its population is increasing, and could achieve similar values of density as those reported in the above-mentioned studies. Of course, this will only occur if selective extraction ceases or is drastically reduced.

Basal area values $\left(30.9 \mathrm{~m}^{2} /\right.$ ha for individuals with $\left.\mathrm{DBH} \geq 4.8 \mathrm{~cm}\right)$ were slightly above the average of other Restinga forests in Brazil (27.3 $\pm 11.1 \mathrm{~m}^{2} /$ ha; Lima et al. 2015 and references therein). The relationship between flooding and basal area that we observed is not supported by the literature, as flooded and periodically flooded sites usually have forests with lower basal areas than unflooded sites (Sztutman \& Rodrigues 2002, Guedes et al. 2006, but see Marques et al. 2009). Restinga soils subjected to flooding usually have higher nutrient availability than dry, well-drained sandy soils (Magnago et al. 2012). In a study that compared flooded and unflooded Restinga forests, the relative growth rate was higher on poorly drained soils than on well-drained soils (Marques et al. 2009). It is possible that species that are able to deal with flooding benefit from the higher levels of nutrients available in these sites and accumulate biomass, so have larger basal areas. Large basal areas may also be related to a relatively advanced successional stage (Chazdon 2003), which is the case in our study site (but see Supplementary Material Table S3).

Although multi-stemmed individuals are considered a common feature of Restinga forests (Silva 1990), the average proportion of multi-stemmed individuals in this study was only $14.6 \%$, which is similar to that found by Lima et al. (2011) in a Restinga forest with a mixture of periodically flooded and unflooded plots in Ilha do Cardoso State Park. The proportion of species with multi-stemmed individuals (53.9\%) was within the range of other Atlantic Forest types (44-68\%; Lima et al. 2011), and lower than the proportion (74\%) observed by Lima et al. (2011) in a Restinga forest in southern São Paulo state. The development of multi-stemmed trees has been related to increased light interception, and resprouting and survival after physical damage (Martini et al. 2008). In our study site, the growth of multi-stemmed trees could be related to both of the above-mentioned factors, as well as the open canopies of Restinga forests (Araújo \& Lacerda 1987, Sugiyama 1998) and soil instability, which is a common feature of flooded sites and can make species more susceptible to uprooting during storm events (Fraser 1962, Kurtz et al. 2013). The consistency in the proportion of multi-stemmed individuals among the three DBH inclusion criteria sampled in our study site indicates that this feature generally appears in trees at early life stages.

The overall species richness (119 species) was relatively high in comparison with the results obtained by previous studies on other Restinga forests with similar sampling efforts. Only two Restinga forest sites in Brazil have had higher richness values reported for trees with a $\mathrm{DBH} \geq 4.8 \mathrm{~cm}$ (Espírito Santo, 159 species and 2 ha sampled, Leite 2010; and Santa Catarina, 128 species and 1 ha sampled, Negrelle 1995). Local environmental heterogeneity may contribute to the establishment of a large number of species (Lundholm 2009). In our study site, variations in environmental features could be mainly related to different levels of waterlogging (Pansonato M.P., pers. obs.) and soil properties. When richness values were rarefied to a common sampling effort (0.64 ha), a richness increase was observed when small individuals were included, probably because of the inclusion of shrub and treelet species in the Myrtaceae, Rubiaceae, and Melastomataceae families.

The Shannon diversity index value was relatively high $\left(\mathrm{H}^{\prime}=3.61\right)$ in comparison to other flooded and unflooded Restinga forests (Menezes et al. 2010 and references therein; Assis et al. 2011 and references therein), particularly considering the high relative abundance of Diospyros brasiliensis (ca. 20\%), which tends to reduce Shannon values due to reduced equability. Restinga forests with lower species richness than our study site have higher values of diversity (e.g., 71 species and 0.5 ha sampled, H' = 3.703, Fabris \& Cesar 1996; 84 species and 0.4 ha sampled, H'=3.897, Urbanetz et al. 2010; 94 species and H' = 3.637 per hectare, Lima et al. 2011), probably because of higher equability among species. The proximity of our study site to continuous areas of rainforest on clayey soils may have facilitated constant colonization by propagules that originated in the continuous forest and this would tend to increase species richness. Furthermore, if local factors in our study site favored the establishment of certain species, they would also have had their density greatly increased by having a source of propagules in nearby rainforests.

As expected, Myrtaceae was the richest family in our study area. This is a major floristic pattern in the Atlantic Forest (Mori et al. 1983, Scudeller et al. 2001). Lauraceae, Fabaceae, Rubiaceae, and Melastomataceae were also very rich families, as previously found in other studies on Restinga forests (Guedes et al. 2006, Lopes 2007, Martins et al. 2008, Assis et al. 2011, Magnano et al. 2012). Our study site was dominated by Diospyros brasiliensis (Ebenaceae), which was the most representative species in terms of density, frequency, and basal area. This species occurs in the coastal plain forests of Rio de Janeiro, São Paulo, and Paraná (Ivanauskas 1997, Santos \& Sano 2007, Martins et al. 2008), as well as in the lowlands and riverine forests. It has also been recorded in semi-deciduous forests in São Paulo and Pernambuco states (Soares et al. 2005, Holanda et al. 2010), although this should be viewed with caution, as the misidentification of this species is common (Santos \& Sano 2007). Despite species identification, the highest density recorded for this species until now was 59 ind./ha in a seasonal semi-deciduous forest in Pernambuco state (Holanda et al. 2010). 
Additionally, this species was found to be dominant in the subcanopy layer of a Restinga forest in a floristic inventory conducted in the nearby municipality of Bertioga, although species abundances were not quantified in this study (Martins et al. 2008). The high abundance of Diospyros brasiliensis in our study site (309 ind./ha or $19.1 \%$ of all individuals for $\mathrm{DBH} \geq 4.8 \mathrm{~cm})$ is, therefore, very peculiar. The high abundance of Anaxagorea dolichocarpa (Annonaceae) (102 ind./ha or $6.3 \%$ of all individuals for $\mathrm{DBH} \geq 4.8 \mathrm{~cm}$ ) is also unusual in Restinga forests.

Sandy coastal plains are geologically recent, and are considered as a subset of species that were originally present in the surrounding Atlantic Forest (Rizzini 1979, Araújo 2000). However, when the densities of some species are compared between coastal plains and adjacent slope forests, they usually differ widely (Scarano 2002, Assis et al. 2011). Some indicator species in coastal plain forests, such as Ilex theezans (Marques et al. 2011), confirm this hypothesis. Calophyllum brasiliense, Andira fraxinifolia, Myrcia multiflora, and Ocotea pulchella are more abundant in Restinga forests than in slope forests along the Brazilian coast (Lima et al. 2015 and references therein). Low floristic similarities between Restinga forests and nearby rainforests on clayey soils may be caused by soil characteristics (Araújo 2000, Assis et al. 2011). However, the unusual abundance of Diospyros brasiliensis and Anaxagorea dolichocarpa in our study site should not be solely attributed to general soil characteristics, but colonization processes such as founder effects (Grime 1998) and mass effects (Shmida \& Ellner 1984) should also be considered. Further studies on species similarity that take into account species abundance are needed, as they would improve our understanding of differences in species distributions between rainforests on clayey soils and Restinga forests, as well among Restinga forests.

Our study site is located in a region under strong anthropogenic pressure with only a few forest fragments remaining. The recent construction of a road across the Caraguatatuba coastal plain has altered the drainage pattern in a small proportion of the southern part of our study site (Pansonato M.P., pers. obs.). This has also occurred in several areas along the BR-101 highway, and has reduced vegetation cover on the coastal plain (Souza 2006). Therefore, the long-term monitoring of the structure and composition of our study site would improve our understanding of the effects of road construction on coastal plain forests in São Paulo. Furthermore, recent ongoing projects related to transport and seaport infrastructure are generating a high demand for compensatory forest restoration on the northern coast of São Paulo. Knowledge of the local vegetation may provide guidelines for the restoration initiatives, and providing information on local species composition could encourage the use of native local species in restoration initiatives. Forest structure data could help to establish restoration strategies that accelerate the recovery of the main attributes of vegetation.

Our study site is important for both biodiversity conservation and ecosystem services. Its location is strategic in connecting slope forests and the coastal plain, and it probably acts as a stepping stone that facilitates the movement of animals (e.g., seed dispersers) across the landscape. In addition, as our study site is one of the largest Restinga forest remnants in the region, it may function as a source of propagules to recolonize nearby smaller fragments, and areas under secondary succession. Because of the high frequency of heavy rain, many areas on the Caraguatatuba coastal plain are frequently flooded (Boulomytis et al. 2015), so the conservation of this Restinga forest remnant is important because it could act as a water sink that mitigates overflow events (Neary et al. 2009). As overflow events are capable of transporting sediments, Restinga forest remnants probably contribute to sediment retention by preventing sediments being deposited in watercourses or urban areas (Carter 1988). Finally, the Restinga forest studied is only partly protected by ecological-economic zoning, which recommends a soil occupation rate of $20 \%$ (Estado de São Paulo, 2017). Given the importance of our study site to the landscape and its proximity to urban areas, we recommend the creation of a Private Reserve of Natural Heritage for its long-term conservation.

\section{Supplementary material}

The following online material is available for this article:

Figure S1 - Rarefaction sample-based curves and their respective confidence intervals. A) $\mathrm{DBH} \geq 4.8 \mathrm{~cm}$. B) $\mathrm{DBH} \geq 10 \mathrm{~cm}$.

Table S1- Parameters of the species sampled for three diameter inclusion criteria of a Restinga forest fragment located on coastal plain of Caraguatatuba, Brazil. N: Number of individuals, Ind./ha: Individuals per hectare, RD: Relative density, BA: Basal area and RDo: Relative dominance. Data ordered by their $\mathrm{N}$ for $\mathrm{DBH} \geq 4.8 \mathrm{~cm}$.

Table S2 - Parameters of the families sampled for three diameter inclusion criteria of a Restinga forest fragment located on coastal plain of Caraguatatuba, Brazil. N: Number of individuals, Ind./ha: Individuals per hectare, RD: Relative density, BA: Basal area, RDo: Relative dominance and Nsp: Number of species. Data ordered by their $\mathrm{N}$ for $\mathrm{DBH} \geq 4.8 \mathrm{~cm}$.

Table S3. Parameters of the 72 species sampled in five secondary plots of a Restinga forest fragment located on coastal plain of Caraguatatuba, Brazil. N: Number of individuals, RD: Relative density and Ind./ha: Individuals per hectare. Data ordered by their $\mathrm{N}$ for DBH $\geq 4.8 \mathrm{~cm}$.

\section{Author Contributions}

Marcelo Petratti Pansonato: Contribution to data collection; Contribution to data analysis and interpretation; Contribution to manuscript preparation; Contribution to critical revision, adding intelectual content.

Renato Augusto Ferreira de Lima: Contribution to data analysis and interpretation; Contribution to critical revision, adding intelectual content.

Alexandre Adalardo de Oliveira: Substantial contribution in the concept and design of the study; Contribution to data analysis and interpretation; Contribution to critical revision, adding intelectual content.

Ricardo Bertoncello: Substantial contribution in the concept and design of the study; Contribution to data analysis and interpretation; Contribution to critical revision, adding intelectual content.

Adriana Maria Zanforlin Martini: Substantial contribution in the concept and design of the study; Contribution to data analysis and interpretation; Contribution to manuscript preparation; Contribution to critical revision, adding intelectual content. 


\section{Conflicts of interest}

The authors declare that they have no conflict of interest related to the publication of this manuscript.

\section{References}

APG. 2016. An update of the Angiosperm Phylogeny Group classification for the orders and families of flowering plants: APG IV. Bot. J. Linn. Soc. 181:1-20.

ARAÚJO, D.S.D. 2000. Análise florística e fitogeográfica das restingas do Estado do Rio de Janeiro. Tese de doutorado, Universidade Federal do Rio de Janeiro, Rio de Janeiro.

ARAÚJO, D. S. D. \& LACERDA, L. D. 1987. A natureza das restingas. Ciência hoje 6(33):42-48.

ASSIS, M. A. D. 1999. Florística e caracterização das comunidades vegetais da planície costeira de Picinguaba, Ubatuba-SP. Tese de doutorado. Universidade Estadual de Campinas, Campinas.

ASSIS, M.A., PRATA, E.M.B., PEDRONI, F., SANCHEZ, M., EISENLOHR, P.V., MARTINS, F.R., SANTOS, F A.M. D., TAMASHIRO, J.Y., ALVES, L.F., VIEIRA, S.A., PICOLLO, M.C., MARTINS, S.C., CAMARGO, P.B., CARMO, J.B., SIMÕES, E., MARTINELLI, L.A. \& JOLY, C.A. 2011. Florestas de restinga e de terras baixas na planície costeira do sudeste do Brasil: vegetação e heterogeneidade ambiental. Biota Neotropica 11(2):103-121. http://www.biotaneotropica.org.br/v11n2/pt/ abstract?article+bn02111022011 (último acesso em 25/03/2017)

BORGES, R. \& PEIXOTO, A. L. 2009. Conhecimento e uso de plantas em uma comunidade caiçara do litoral sul do Estado do Rio de Janeiro, Brasil. Acta Bot. Bras. 23(3):769-779.

BOULOMYTIS, V.T.G., SANTANA, M.F., DA COSTA, L.S.D. \& SANTOS, A.P. 2015. Metodologia de apoio aos gestores urbanos para o mapeamento de inundações: caso da bacia do rio Juqueriquerê, Caraguatatuba, SP. Caminhos de Geografia 16(53):164-175.

CARRASCO, P.G. 2003. Produção de mudas de espécies florestais de restinga, com base em estudos florísticos e fitossociológicos, visando a recuperação de áreas degradadas, em Ilha Comprida - SP. Tese de doutorado. Universidade Estadual Paulista Júlio de Mesquita Filho, Rio Claro.

CARTER, R.W.G. 1988. Coastal environments: an introduction to the physical, ecological and cultural systems of coastlines. Academic Press, London.

CARVALHAES, M.A. 1997. Florística e estrutura de mata sobre restinga na Juréia, Iguape, SP. Dissertação de mestrado, Universidade de São Paulo, São Paulo.

CEPAGRI. Centro de pesquisas meteorológicas e climáticas aplicadas à agricultura. 2016. http://www.cpa.unicamp.br/outras-informacoes/clima muni_121 (último acesso em 25/10/2016)

CÉSAR, O. \& MONTEIRO, R. 1995. Florística e fitossociologia de uma floresta de restinga em Picinguaba (Parque Estadual da Serra do Mar), Município de Ubatuba-SP. Naturalia 20(1):21-35.

CHAZDON, R. L. 2003. Tropical forest recovery: legacies of human impact and natural disturbances. Persp. in Plant Ecol. Evol. Syst. 6(1):51-71.

CHAZDON, R. L., PERES, C. A., DENT, D., SHEIL, D., LUGO, A. E., LAMB, D., STORK, N.E. \& MILLER, S. E. 2009. The potential for species conservation in tropical secondary forests. Conserv. Biol. 23(6):1406-1417.

ESTADO DE SÃO PAULO. Decreto Estadual no 62.913/2017, que dispõe sobre a revisão do Zoneamento Ecológico-Econômico do Setor do Litoral Norte, Disponível em: http://arquivos.ambiente.sp.gov.br/cpla/2011/05/ decreto_estadual_62913_2017_zee_ln.pdf. Acesso em 24/07/2018.

FABRIS, L.C. \& CÉSAR, O. 1996. Estudos florísticos em uma mata litorânea no sul do estado do Espírito Santo, Brasil. Bol. Mus. Biol. Mello Leitão 5:15-46.

FRASER, A. I. 1962. The soil and roots as factors in tree stability. Forestry: An Inter. Jo. of For. Res. 34(2):117-127.

GALVÃO, F., RODERJAN, C.V., KUNIYOSHI, Y.S. \& ZILLER, S.R. 2002. Composição florística e fitossociologia de caxetais do litoral do Estado do Paraná-Brasil. Floresta 32(1):17-39.
GRIME, J. P. 1998. Benefits of plant diversity to ecosystems: immediate, filter and founder effects. J. Ecol. 86(6): 902-910.

GUEDES, D., BARBOSA, L.M. \& MARTINS, S.E. 2006. Composição florística e estrutura fitossociológica de dois fragmentos de floresta de restinga no Município de Bertioga, SP, Brasil. Acta Bot. Bras. 20(2):299-311.

HOLANDA, A.C.D., FELICIANO, A.L.P., MARANGON, L.C., SANTOS, M.S.D., MELO, C.L.S.M.S. \& PESSOA, M. M. D. L. 2010. Estrutura de espécies arbóreas sob efeito de borda em um fragmento de floresta estacional semidecidual em Pernambuco. Rev. Árv. 34(1):103-114.

IVANAUSKAS, N.M. 1997. Caracterização florística e fisionomia da Floresta Atlântica sobre a formação Pariquera-Açu, na zona da morraria costeira do Estado de São Paulo. Dissertação de mestrado, Universidade Estadual de Campinas, Campinas.

KURTZ, B. C., GOMES, J. C., \& SCARANO, F. R. 2013. Structure and phytogeographic relationships of swamp forests of Southeast Brazil. Acta Bot. Bras. 27(4):647-660.

LEITE, V.R. 2010. Análise estrutural e da vulnerabilidade ambiental de um fragmento florestal de restinga ao sul do estado do Espírito Santo. Dissertação de mestrado, Universidade Federal do Espírito Santo, Jerônimo Monteiro.

LIMA, R. A. F. D., OLIVEIRA, A. A. D., MARTINI, A. M. Z., SAMPAIO, D., SOUZA, V. C. \& RODRIGUES, R. R. 2011. Structure, diversity, and spatia patterns in a permanent plot of a high Restinga forest in Southeastern Brazil. Acta Bot, Bras. 25(3):633-645.

LIMA, R. A., MORI, D. P., PITTA, G., MELITO, M. O., BELLO, C., MAGNAGO, L. F., ZWIENER, V. P., SARAIVA D. D., MARQUES, M.C.M., DE OLIVEIRA, A.A. \& PRADO, P. I. 2015. How much do we know about the endangered Atlantic Forest? Reviewing nearly 70 years of information on tree community surveys. Biodivers. Conserv. 24(9):2135-2148.

LOPES, E.A. 2007. Formações florestais de planície costeira e baixa encosta e sua relação com o substrato geológico das bacias dos rios Itaguaré e Guaratuba. Tese de doutorado, Instituto de Botânica, São Paulo.

LUNDHOLM, J.T. 2009. Plant species diversity and environmental heterogeneity: spatial scale and competing hypotheses. J. Veg. Sci. 20:377-391.

MAGNAGO, L. F. S., MARTINS, S. V, SCHAEFER, C. E. G. R., \& NERI, A. V. 2012. Restinga forests of the Brazilian coast: richness and abundance of tree species on different soils. Anais Acad. Bras. Ciências 84(3):807-22.

MAGURRAN, A.E. 1988. Ecological diversity and its measurement. Princeton, Princeton University Press.

MANTOVANI, W. 1992. A vegetação sobre a restinga de Caraguatatuba, SP. Rev. Inst. Flor. 4(1):139-144.

MARQUES, M. C., BURSLEM, D. F., BRITEZ, R. M., \& SILVA, S. M. 2009. Dynamics and diversity of flooded and unflooded forests in a Brazilian Atlantic rain forest: a 16-year study. Plant Ecol. Divers. 2(1):57-64.

MARQUES, M. C., SILVA, S. M., \& LIEBSCH, D. 2015. Coastal plain forests in southern and southeastern Brazil: ecological drivers, floristic patterns and conservation status. Braz, J. of Bot. 38(1):1-18.

MARQUES, M.C.M., SWAINE, M.D. \& LIEBSCH, D. 2011. Diversity distribution and floristic differentiation of the coastal lowland vegetation: implications for the conservation of the Brazilian Atlantic Forest. Biodivers. Conserv. 20(1):153-168.

MARTINI, A.M.Z.; LIMA, R.A.F.; FRANCO, G.A.D.C. \& RODRIGUES, R.R 2008. The need for full inventories of tree modes of disturbance to improve forest dynamics comprehension: An example from a semideciduous forest in Brazil. For. Ecol. Manag. 255:1479-1488.

MARTINS, S.E., ROSSI, L., SAMPAIO, P.D.S.P. \& MAGENTA, M.A.G. 2008. Caracterização florística de comunidades vegetais de restinga em Bertioga, SP, Brasil. Acta Bot. Bras. 22(1):249-274.

MAUN, M.A. 1994. Adaptations enhancing survival and establishment of seedlings on coastal dune systems. Vegetatio 111:59-70.

MENEZES, L. F. T. D., ARAUJO, D. S. D. D. \& NETTESHEIM, F. C. 2010. Estrutura comunitária e amplitude ecológica do componente lenhoso de uma floresta de restinga mal drenada no sudeste do Brasil. Acta Bot. Bras. 24(3):825-839. 
MORI, S. A., BOOM, B. M., \& DE CARVALINO, A. M. 1983. Ecological importance of Myrtaceae in an eastern Brazilian wet forest. Biotropica 15(1):68-70.

NEGRELLE, R.R.B. 1995. Composição florística, estrutura fitossociológica e dinâmica de regeneração da Floresta Atlântica na Reserva Volta Velha, mun. Itapoá, SC. Tese de doutorado, Universidade Federal de São Carlos, São Carlos.

NEARY, D.G., ICE, G.G. \& JACKSON, C.R. 2009. Linkages between forest soils and water quality and quantity. Forest Ecol. Manag. 258(10):2269-2281.

OKSANEN, F., BLANCHET, G., KINDT, R., LEGENDRE, P., MINCHIN, P.R., O'HARA, R.B., SIMPSON, G.L., SOLYMOS, P., STEVENS, M.H.H. \& WAGNER, H. 2016. Vegan: community ecology package. R package version 2.3-5.

OLIVEIRA, A. A., VICENTINI, A., CHAVE, J., CASTANHO, C. D. T., DAVIES, S. J., MARTINI, A. M., LIMA, R. A. F., RIBEIRO, R. R., IRIBAR, A. \& SOUZA, V. C. 2014. Habitat specialization and phylogenetic structure of tree species in a coastal Brazilian white-sand forest. J. Plant Ecol. 7(2):134-144.

OLIVEIRA, J.B., CAMARGO, M.N., ROSSI, M. \& CALDERANO FILHO, B. 1999. Mapa pedológico do Estado de São Paulo: legenda expandida. Campinas: Instituto Agronômico, Embrapa Solos. 64 p. Escala 1:500.000.

RIZZINI, C. T. 1979. Tratado de fitogeografia do Brasil. v.2. Edusp, São Paulo.

ROTTA, E., BOERGER, M.R.T. \& GRODZKI, L. 1997. Levantamento florístico e fitossociológico de um trecho de Floresta Ombrófila Densa das Terras Baixas no Parque Estadual do Palmito, Paranaguá, PR. Braz. Arch. Biol. Tech. 40b:849-861.

SANTOS, M.F. \& SANO, P.T. 2007. Ebenaceae. In Flora Fanerogâmica do Estado de São Paulo (T.S. Melhem, M.G.L. Wanderley, S.E. Martins, S. L. Jung-Mendaçolli, G.J. Shepherd \& M. Kirizawa, eds.). Instituto de Botânica, São Paulo, v.5, p. 195-199.

SCARANO, F. R. 1998. A comparison of dispersal, germination and establishment of woody plants subjected to distinct flooding regimes in Brazilian flood prone forests and estuarine vegetation. Oecol. Austr. 4(1): 177-193.
SCARANO, F.R. 2002. Structure, Function and Floristic Relationships of Plant Communities in Stressful Habitats Marginal to the Brazilian Atlantic Rainforest. Ann. Bot. London. 90(4):517-524.

SCUDELLER, V. V., MARTINS, F. R., \& SHEPHERD, G. J. 2001. Distribution and abundance of arboreal species in the atlantic ombrophilous dense forest in Southeastern Brazil. Plant Ecol. 152(2):185-199.

SHEPHERD, G. 2009. Fitopac v. 2.0. Universidade Estadual de Campinas, Campinas.

SHMIDA, A. \& ELLNER, S. 1984. Coexistence of plant species with similar niches. Plant Ecol. 58(1):29-55.

SILVA, S. M. 1990. Composição florística e fitossociologia de um trecho de floresta de restinga na Ilha do Mel, Município de Paranaguá, PR. Dissertação de mestrado, Universidade Estadual de Campinas, Campinas.

SOARES, M.S., SOARES, J.J. \& LIMA, M.I.S. 2005. Florística e fitossociologia de mata estacional semidecidual denominada "São Pedro" em Araras - SP. In: Anals of the $56^{\circ}$ Botany National Congress. Curitiba, p. 2055.

SOUZA, C.R.G. 2006. Mapeamento de compartimentos fisiográficos de planície costeira e baixa-encosta e da vegetação associada, no litoral norte de São Paulo. In VI Simpósio Nacional de Geomorfologia. Goiânia, p1-11.

SOUZA, C.R.G. \& LUNA, G. 2008. Unidades quaternárias e vegetação nativa de planície costeira e baixa encosta da Serra do mar no litoral norte de São Paulo. Rev. Inst. Geol. 29:1-18.

SUGIYAMA, M. 1998. Estudo de florestas da Restinga da Ilha do Cardoso, Cananéia, São Paulo, Brasil. Bol. Inst. Bot. 11:119-159.

SZTUTMAN, M. \& RODRIGUES, R.R. 2002. O mosaico vegetacional numa área de floresta contínua da planície litorânea, Parque Estadual da Campina do Encantado, Pariquera-Açu, SP. Rev. bras. bot. 25(2):161-176.

URBANETZ, C., TAMASHIRO, J.Y. \& KINOSHITA, L.S. 2010. Floristic composition and similarity analysis of an atlantic rain forest fragment in Cananéia, São Paulo State, Brazil. Rev. bras. bot. 33(4):639-651.

VANINI, A. 1999. Estudo comparativo de dois métodos de amostragem fitossociológica em Caxetais (floresta ombrófila densa permanentemente alagada). Dissertação de mestrado, Escola Superior de Agricultura Luiz de Queiroz, Piracicaba. 